\title{
Engaging students through ICT: strategies and challenges for using website in teaching and learning
}

\author{
Aliff Nawi ${ }^{1, *}$, Ahmad Fkrudin Mohamed Yusoff ${ }^{2}$, Hafit Hidayah Ajmain $^{3}$, \\ Mohamad Raffe Ghalil Abbas ${ }^{3}$ \\ ${ }^{1}$ Sultan Hassanul Bolkiah Institute of Education, Universiti Brunei Darussalam, \\ Tunku Link Road, BE1410, Brunei \\ ${ }^{2}$ Department of General Studies, Politeknik Ungku Omar, Jalan Raja Musa Mahadi, \\ 31400 Ipoh, Perak, Malaysia \\ ${ }^{3}$ Faculty of Education, Universiti Kebangsaan Malaysia, 43600 Bangi, \\ Selangor, Malaysia \\ *E-mail address: aliffnawi@yahoo.com
}

\begin{abstract}
The existence of website made the world without borders and all the information is just a few clicks away. In the education field, the usage of internet and websites in teaching and learning (T\&L) will facilitate access to information for reference purposes regardless of time and place. This study discusses the use of web application in T\&L as an attraction to students. The study utilizes the qualitative methods which are literature reviews and document analysis. In conclusion, teachers should be innovative and creative in diversifying their teaching methods, including the use of websites to make T\&L more interesting and thus, enhance their professional skills.
\end{abstract}

Keywords: Website-based Teaching and Learning; Islamic Education; teaching and learning

\section{INTRODUCTION}

Website-based Teaching and Learning (T\&L) is a concept that integrates information and communication technologies in the education system. In the world of education, all academicians including teachers need to master the latest information technology to encourage the integration of ICT in the process of T\&L. Through this, maximum effectiveness of T\&L could be achieved and moreover, web-based teaching could meet the needs and the latest educational situation of students.

In this way, students not only have access to information and teaching materials via the web, but they are also able to engage in learning activities that include virtual discussion sessions, knowledge structuring, and creating an environment for self-paced learning at anytime and anywhere. Apart from the active involvement of students in the learning process through the web that can produce students who are critical and creative thinkers, it is also able 
to improve the level of learning process among students (Chang 2001). This indicates that websites are relevant teaching materials in the era of technology now.

In order to build human capital, as intended by the National Education Philosophy, the delivered knowledge should be in accordance with current developments and requirements of the nation. World Wide Web (www) is a system that is able to present the information in the form of multimedia with a combination of text, images, sound and video (Mohd Arif \& Mohd Jasmy 2000). The internet and websites can be used as sources of information and media in the process of T\&L widely in the field of education. Internet is a technology that acts as an information dissemination tool that enables individual interactions with the computer, individuals with individuals without limitations of time and geography.

\section{STATEMENT OF PROBLEM}

Education is not merely to make students know how to read, but to be able to think in a rational manner, knowledge-seeking and know how to survive. To achieve these objectives, the T\&L methods must be innovative and effective for the students of this digital era. Teachers should be wise in using multimedia to meet the expectations of the 'digital smart' students and must be able to combine the teaching and multimedia techniques so that every subjects will becomes more interesting and competitive.

Moreover, without denying the benefits obtained by the practice of conventionalteaching, it still has deficiencies. Among the weaknesses of 'old'-teaching are the process of T\&L will be stiff, students easily become bored and sleepy in class (Ab Halim et al. 2010). Moreover, the process of T\&L would be one way without being able to find out whether the message delivered was well received by students.

Furthermore, there are many other aspects that could be the factor of decreased teaching effectiveness which includes the dependency on the thick textbooks as sole reference source (Smaldino et al., 2005). Techniques used by the teachers greatly influence the students' mastery of the subject. What is even more alarming is the old way of teaching will create an atmosphere or climate of learning that can cause stress to the students because teachers are only concerned with the theories without practical and more focused on exams.

Thus the answer to the shortcomings of the teacher is to be active and creative so that their teaching will give a really good impact on the students. The multimedia can help overcome these problems and shortcomings. Multimedia can be of help because its usage can control the stream of knowledge, able to create a conducive T\&L environment. Thus, it can produce students who are excellent and meet the needs of the country.

\section{WEB-BASED LEARNING STRATEGY}

The website can be used as a source for the preparation of a variety of materials and information related to the process of T\&L. Usage of multimedia and web sites in the T\&L process is not meant to replace teachers but to create a more enjoyable, effective and meaningful atmosphere of teaching and learning for the students (Isham Shah 2005). In the present century, the most encouraged T\&L is still student-centered approach but teachers must maximize their role to actively engage students in learning activities. Teachers should also act in facilitating role and as information providers. 
This approach begins with a demonstration session where at an early stage, the teacher guides on the skills but not nearly as detailed as the behavioral approach. Students will try the skills shown as a group under the guidance of teachers. The teacher's support is gradually reduced until students are able to independently complete the project. In theory, the constructivist approach does not focus on how to implement the lesson.

There are numerous suggestions on how students learn has been presented based on the principles of constructivism. Among them is the teacher should relate past experiences of students in all of the learning process, teachers should emphasize the high level of thinking or reasoning for problem solving, students are allowed to use the opportunity to highlight their creativity and class is considered as a place to encourage students to work in groups to solve problems.

\section{1. Self-Study}

Self-study gives students the freedom to control their own learning. Students can learn the difficult topics over and over again until an understanding is reached. Apart from students being the main focus, this learning method requires the support of other factors such as family, educational facilities or the environment is also responsible for self-paced learning.

According to Roger (1994) self-study is equal to the change and growth of a person. According to Roger, the teachers are only facilitators in the process of $T \& L$ and their tasks are outlined as follow:

i. Building a positive learning environment

ii. Explaining the purpose of students

iii. Compile and build the source of information

iv. Balancing between intelligence and emotional components

v. Sharing feelings and thoughts with students rather than trying to dominate it.

Therefore, the use of websites in teaching Islamic Education is seen appropriate for the nature of a student who likes to explore. However, the boom of globalization makes the world's dimensions more different and the teachers face more challenges due to occurrence of too much of information online (Mohd Aliff et al. 2012). This matter should be considered by teachers fearing that students may mistakenly use the website for the purpose of their learning.

\section{2. Situation-Based Learning}

WebQuest is an example of a situation-based learning that has an important role in building construct-teaching method. Students can actively construct their own understanding based on a topic that was created by the teacher. Questions or problems of real-life situations built to provide experience to students in looking for solutions to problems in a cooperative manner. In this context, learning through WebQuest has an important role in building comprehension based on topics learned.

According to Norazah and Ngau (2009), web-based T\&L aimed at providing facilities to educators in managing teaching materials, create an effective learning environment, and induces active participation of students in the process of T\&L is very suitable as an alternative in the process ICT teaching. WebQuest is an inquiry activity that directs part or all of the information obtained from the Internet by students. 
Rhynard (2002) also listed some of the WebQuest usage advantages:

i) the students are directed to focus on the web page where the main focus is the information that will be used in the WebQuest,

ii) learning objectives are clear,

iii) there is limits to the amount of information available,

iv) the information are valid and reliable,

v) flexible in which a student may stop or start of a web page to obtain information at any point of time. In addition, the WebQuest is also suitable for any subjects and topics.

\section{3. Problem-Based Learning}

This type of learning is one of the approaches based on the constructivist theory, apart from other learning approaches such as cooperative learning, project and situations based learning. According to Savery and Duffy (1995), problem-based learning (PBL) would be more meaningful by integrating the features of cooperative learning; project and situations based learning which can make the learning environment more meaningful.

PBL helps students achieve a specific level of learning to make them competent and capable. For example, being able to adapt to the changes, can manage various problems with critical and creative thinking by finding the causes and consequences of a problem or phenomenon. Moreover, students will also be able to identify their strengths and weaknesses and be able to work effectively in groups. Due to that, the PBL can help and influence their learning more effectively.

According to Zaharatul Laili and Ramlee (2007), PBL makes students more responsible, active in learning and more independent. In other words, students will be able to learn on their own and teachers act just as facilitator or guide. Here, they realized that in PBL they need to better understand the problem and how to solve it. Graaff and Kolmos (2005) stated that PBL is an approach of teaching and learning where the problem is a starting point to the learning process. Often, the problem is selected based on the actual problems encountered and adapted to teachers' learning objectives and criteria.

\section{4. Project-Based Learning}

Through the project-based learning, students can use the web-based learning courses to communicate, collaborate and publish personal material in the interaction between teachers and students. This will enable the students to access wider and reasonable learning resources through the web link comfortably.

Generally good project management and implementation of properly planned projects should be helped by the teachers at the initial stage as a first experience to students in projectbased learning task. Once guidance and mentoring provided and students have experience to manage the project, then the teacher may do other projects to enhance their knowledge and develop their skills.

According to Seidel and Godfrey (2005), problems that arise from open-ended project work is about the burden of students' work load. This is very important for students who are more likely to take short cuts or spend too much time on the project. Specifically, the projects 'real life' based, the students will have more fun and drag on with the project work. In order to overcome this problem, the teacher should set a fixed amount of time to complete the project given to the students. 


\section{5. Learning through the Forum}

Learning through forum provides space for teachers to interact with students and students can also interact with each other to get additional help and information. It is thus able to generate ideas and thoughts in giving opinions and information to their cyber friends. Their choice is also a chat room that allows them to interact simultaneously in discussing current topics of their choice. This gives them the opportunity to experience a new virtual communication interaction (Mohd Nawi et al. 2013). They are free to ask and respond without feeling embarrassed compared to face-to-face interaction.

The style of interaction between teacher and students today has experienced a paradigm change on how interactions are more directed while gaining insights from fellow students through e-learning. Learning through forums or online made the patterns of learning different than conventional learning. According to Resnick (2002), the on-line learning process by no longer rely on teachers but more student-centered (student instructor-centered learning or independent). Teachers are also no longer seen as the main reference but as a facilitator or consultant. Students should be trusted to give opinion and determine attitude.

\section{ISSUES OF WEB-BASED LEARNING}

Every teacher must enhance their existing knowledge and experience to be able to give more than expected to their students. Students today are also not easily satisfied only with what they acquire in the classroom. Their curiosity is high and they expect answers to all their questions and concerns from their teachers. Therefore, the teachers involved in the teaching of Islamic Education in particular need to expand their T\&L process, to make it fun to learn. However, according to Rahimi et al. (2005) there are 3 major challenges faced by teachers in implementing website-based learning.

\section{1. Limited Infrastructure}

To implement website-based learning, there are few needs that should be fulfilled. Various important equipment such as computers, Internet lines, mobile phones and televisions should be made available for learning sessions. Unfortunately, adequate telecommunication facilities have yet to be fulfilled as demanded.

There are still schools that do not have Internet access as a whole. As a result of this, whiteboard, overhead projector and module / textbook are still the popular mediums of instruction in most classes. The main cause for this is the lack of proper and comprehensive equipment in schools especially in rural schools. Matter needs to be addressed properly by the authorities so that web-based learning can be implemented as a whole, including the T\&L of Islamic Education.

\section{2. Skills of Teachers}

The success of learning and teaching methodologies through the website will need to take into account other factors, including support from the management team to implement web-based learning and training for teachers. This is because the computer interact skills is the basic skill that must be mastered by teachers because they are the prime movers of and they could determine the success of this project. 
For teachers of Islam Education, most of them are not software developers and most of them are not interested in developing software for teaching purposes (Ab. Halim \& Zaradi 2007; Baharudin Shidki \& Nik Rahimi 2008). It shows the constraints among teachers that does not have the skills and lack of interest in software development in Islamic Education.

\section{3. The Content of Websites}

Website-based learning also had to deal with the syllabus prescribed by the page developers. This makes it not parallel with the school syllabus. To adjust the syllabus, they had to move to another page to fit the syllabus. If studied, some sites are providing a distinctive curriculum that may not fit the learning environment for students.

In addition, there are websites that are less in promoting noble values. Without a teacher who acts as a facilitator, students using web-based learning methods could fail to master effective learning or gain knowledge that is not valid. Besides the challenge for teachers is that they should not only be users, instead they should try to develop their own software compatible with our curriculum.

\section{SUMMARY AND RECOMMENDATIONS}

In general, to increase the use of websites in teaching Islamic Education, the participation of all from the lower level through to senior administration should play their role and should cooperate and work to overcome the obstacles that arise. In addition, the emphasis on the use of ICT is also noteworthy because these needs are corresponding.

The teachers also should be ready to change the focus from teacher-centered teaching to student-centered learning. Then it shall not be denied that the use of web is one of the teaching methods that are suitable at the moment, compared to the typical conventional approach. Therefore, the web building activities through the Internet as a medium or tool to disseminate education information globally should already be commenced by teachers.

At the present time, there are specific software to develop website easily like wordpress, BlogSpot, Facebook, Ning and tripod. In the event of us not able to build it, we can use websites dedicated to education that have been developed by others for free from all over the world. Teachers should be ready to prepare a community that can compete globally in the future.

\section{Biography}

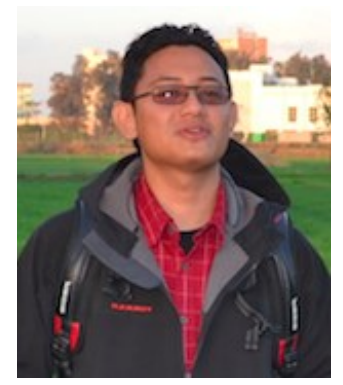

Aliff NAWI is a Research Assistant and PhD candidate at the Sultan Hassanul Bolkiah Institute of Education, Universiti Brunei Darussalam. He obtained his M.Ed. in Islamic Education from Universiti Kebangsaan Malaysia with a thesis on Mobile Learning in Islamic Education. His current research is on Islamic values and educational technology.

E-mail: aliffnawi@yahoo.com 


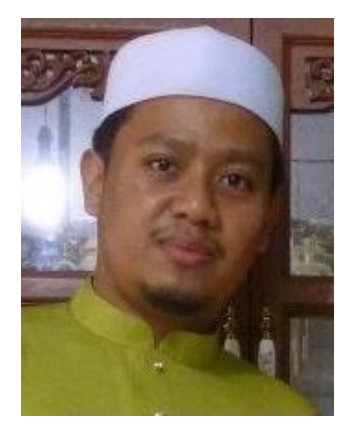

Ahmad Fkrudin MOHAMED YUSOFF is a senior lecturer in Department of General Studies, Politeknik Ungku Omar, Perak. He graduated from Universiti Teknologi Malaysia (B.Ed. in Islamic Education) and Universiti Kebangsaan Malaysia (M.Ed. in Islamic Education). He teachs various subject in Politeknik including Islamic Education and Islamic Civilization.

E-mail : fkrudin@jpa.puo.edu.my

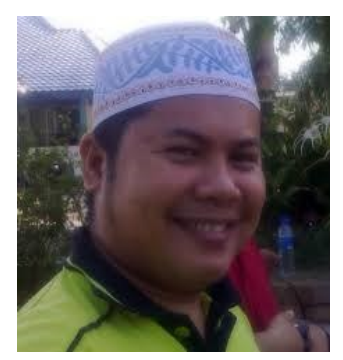

Mohamad Raffe GHALIL ABBAS is a Master candidate at Faculty of Education, Universiti Kebangsaan Malaysia. He graduated with a bachelor's degree (Islamic Studies) from Al-Azhar Universiti. He teachs various subjects including Islamic Education and Tarannum Al-Quran at schools and colleges in Selangor.

E-mail : effar76@gmail.com

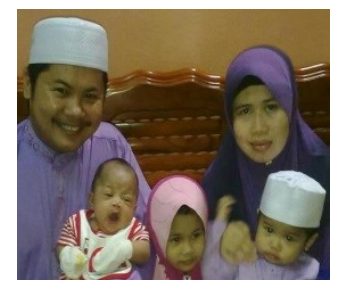

Hafit Hidayah AJMAIN is Raffe's wife. She also a Master candidate at Faculty of Education, Universiti Kebangsaan Malaysia. She graduated with a bachelor's degree (Islamic Education) from Institut Perguruan Tuaran, Sabah. She teachs Islamic Education and Tajwid Al-Quran at School in Selangor.

E-mail : hafit.day@gmail.com

\section{References}

[1] Ab. Halim Tamuri, Nik Mohd Rahimi Nik Yusoff (2010). Isu pengajaran dan pembelajaran pendidikan Islam. In: Ab. Halim Tamuri and Nik Mohd Rahimi Nik Yusoff (eds.). Kaedah Pengajaran dan Pembelajaran Pendidikan Islam. Bangi: Universiti Kebangsaan Malaysia Press, pp. 19-37.

[2] Baharuddin Shidki, Nik Rahimi (2008). Cabaran Penggunaan ICT dalam Pengajaran dan Pembelajaran Pendidikan Islam. Dlm. Norazah Mohd Nordin \& Mohamed Amin Embi (eds.). Pengintegrasian ICT dalam Pendidikan, Penyelidikan, Amalan dan Aplikasi, pp. 47-62.

[3] Chang Chi-Cheng, British Journal of Educational Technology 32(4) (2001) 435-459.

[4] Graaff E., Kolmos A., International Journal of Engineering Education 19(5) (2003) 657-662.

[5] Isham Shah Hassan (2005). Penggunaan Laman Web Multimedia Interaktif Sebagai Media Pembelajaran Untuk Pelajar Diploma Seni Bina Politeknik Port Dickson: Konvensyen Teknologi Pendidikan Negeri Sembilan.

[6] Mohd Aliff Mohd Nawi, Ezad Azraai Jamsari, Mohd Isa Hamzah, Adibah Sulaiman, Azizi Umar, Australian Journal of Basic and Applied Sciences 6(8) (2012) 74-78. 
[7] Mohd Arif Ismail, Mohd Jasmy Abd Rahman (2000). Pembinaan Laman Web Pembelajaran: Fokus terhadap kursus GE 2123: Teknologi dan Inovasi Dalam Pendidikan. Prosiding Seminar Pendidikan Kebangsaan 2000, pp 254-262.

[8] Nawi M. A. M, Jamsari E. A., Sulaiman A., Hamzah M. I., Turkish Online Journal of Distance Education 14(1) (2013) 74-78.

[9] Norashikin Sahadan, Helyawati Baharudin (2010). Rekabentuk Pembangunan Sistem Pembelajaran Berasaskan Situasi Menerusi Web Bagi Tajuk Topologi Rangkaian Dalam Pendidikan. Proceedings Of Regional Conference On Knowledge Integration In ICT 2010, pp. 681-682.

[10] Norazah Mohd Nordin, Ngau Chai Hong, Jurnal Pendidikan Malaysia 34(1) (2009) 111-129.

[11] Seidel R., Godfrey E. (2005). Project and Team based Learning: An Integrated Approach to Engineering Education. Proceedings of the 2005 ASEE/AaeE 4th Global Colloquium on Engineering Education, pp. 146.

[12] Ramlee Mustapha, Zaharatul Laili Abdul Rahim, Jurnal Teknologi 49 (2008) 109-127.

[13] Rogers C. R., Freiberg H. J. (1994). Freedom to Learn (3rd Ed). Columbus, OH: Merrill/Macmillan.

[14] Resnick M. (2002). Rethinking Learning in the Digital Age. In. Porter, M. E., Sachs, J. D., Dan McArthur, J. W. The Global Information Technology Report 2001-2002: Readiness for the Networked World.

[15] Saemah Rahman, Siti Fatimah Mohd. Yassin, Jurnal Pendidikan 33 (2008) 81-94.

[16] Savery J. R., Duffy T. M., Educational Technology 35(5) (1995) 38-68.

[17] Smaldino S. E., Russell J. D., Heinich R., Molenda M. (2005). Instructional media and technologies for learning (8th ed.). Upper Saddle River, NJ: Prentice Hall.

[18] Zaharatul Laili Abdul Rahim, Ramlee Mustapha (2007). Pembelajaran Berasaskan Masalah Bagi Subjek Elektronik: Satu Kajian Tindakan Di Sekolah Menengah Teknik. Seminar Pendidikan Kejuruteraan dan Alam Bina, pp. 230-251.

[19] Rahimi Md. Saad, Zawawi Ismail, Wan Nordin Bin Wan Abdullah (2005). Pengajaran dan Pembelajaran Bahasa Arab Berasaskan Web. Kertas kerja seminar Seminar Penyelidikan Pendidikan Maktab Perguruan Baru Lintang. 15-16 September.

[20] Rhynard M. (2002). The WebQuest as an Instructional Strategy. In C. Crawford et al. (eds.), Proceeding of Society for Information Technology and Teacher Education International Conference 2002, pp. 2397. 